\title{
Oversummer Survival of Inoculum for Colletotrichum Crown Rot in Buried Strawberry Crown Tissue
}

\author{
A. R. Ureña-Padilla, University of Florida, Gulf Coast Research and Education Center, 13138 Lewis Gallagher \\ Road, Dover 33527; D. J. Mitchell, University of Florida, Department of Plant Pathology, P.O. Box 110680, \\ Gainesville 32611; and D. E. Legard, University of Florida, Gulf Coast Research and Education Center, 13138 \\ Lewis Gallagher Road, Dover 33527
}

\begin{abstract}
Ureña-Padilla, A. R., Mitchell, D. J., and Legard, D. E. 2001. Oversummer survival of inoculum for Colletotrichum crown rot in buried strawberry crown tissue. Plant Dis. 85:750-754.

The oversummer survival of Colletotrichum gloeosporioides in strawberry crown tissue under field conditions was investigated in 1998 and 1999. Strawberry crowns infected naturally with C. gloeosporioides were placed inside cloth bags containing field soil, buried in the field at 5 or $13 \mathrm{~cm}$, then recovered over 6 months of each year. The recovered crowns were plated onto a Colletotrichum spp. semiselective medium and speciated by colony, spore morphology, and molecular markers with species-specific DNA primers. Pathogenicity of selected isolates was confirmed by greenhouse bioassays on strawberry. Of the 428 isolates of Colletotrichum spp. recovered from buried crowns, $96 \%$ were C. gloeosporioides and $4 \%$ Colletotrichum acutatum. Following an initial increase in the detection of the fungus, survival of $C$. gloeosporioides was stable for 2 to 3 weeks, then declined. No Colletotrichum spp. were detected after burial for 56 days in 1998 and 98 days in 1999. Because the time between crop seasons is typically more than 170 days, these data support the hypothesis that inoculum of $C$. gloeosporioides does not survive in buried plant debris between seasons in Florida and, therefore, oversummering crop debris does not contribute inoculum for epidemics of Colletotrichum crown rot in Florida.
\end{abstract}

Additional keywords: anthracnose, Fragaria $\times$ ananassa

Strawberries are grown as an annual winter crop in west-central Florida. Greentop transplants obtained from nurseries in the northeastern United States or southeastern Canada are set in late September through early November on methyl bromide-fumigated, plastic-mulched beds. Fruit are harvested in late November through early April (1). At the end of the harvest season, growers destroy plants by applying herbicide or mowing the tops off the plants. Some growers plant spring vegetable crops into the existing beds after killing the strawberry plants. From April to late May, a grain or legume cover crop typically is planted. During August or early September, the cover crop is incorporated and raised beds are formed and fumigated with a mixture of methyl bromide and chloropicrin. In Florida, only the beds are fumigated and strawberries are grown in the same location every season without crop rotation.

Corresponding author: D. E. Legard

E-mail: legard@ufl.edu

Florida Agricultural Experiment Station Journal Series R-07654.

Accepted for publication 24 April 2001.

Publication no. D-2001-0521-01R

(C) 2001 The American Phytopathological Society
Colletotrichum spp. cause a wide range of strawberry diseases. Diseases of fruit, crown, and roots can result in serious yield losses $(4,8,10,11)$. Many of these diseases have been called anthracnose because of the production of typical symptoms, which include limited necrotic lesions and hypoplasia of tissues and fruit $(13,18)$. Plants with symptoms of Colletotrichum crown rot exhibit a sudden wilt of the entire plant. Within the crown, reddish brown necrotic streaks develop in the vascular tissue (20), and eventually the entire crown becomes discolored and the plant dies (11). In Florida, crown rot typically kills 2 to $4 \%$ of plants each season (D. E. Legard, unpublished data), although losses of up to $80 \%$ have occurred when conditions are conducive for serious outbreaks (14). Colletotrichum acutatum, Colletotrichum fragariae, and Colletotrichum gloeosporioides (teleomorph Glomerella cingulata) are the three major Colletotrichum species reported to cause crown rot in strawberry $(2,3,9,11,14,19)$. Recent Colletotrichum spp. crown rot epidemics in Florida have been caused predominately by $C$. gloeosporioides $(15,25)$.

The source of primary inoculum for epidemics of Colletotrichum spp. crown rot of strawberry in Florida is unclear. Transplants are the most likely source of primary inoculum $(8,14)$, and transplants infected or infested with Colletotrichum spp. have been found in California (7), Louisiana (16), and Israel $(8,9)$. Epidemics also originate from other sources of inoculum $(7,12,27)$. In California, Colletotrichum acutatum overwintered in strawberry plant debris for up to 9 months in fields that were not fumigated with methyl bromide (7), and in Ohio, it was overwintered in mummified fruit buried in soil between seasons (27). Horn and Carver (12) suggested that inoculum might survive in crown tissue because $C$. fragariae could be isolated from crowns stored at $5^{\circ} \mathrm{C}$ over 30 weeks. It has been suggested that Colletotrichum spp. associated with strawberry are not likely to survive between seasons in soil or buried plant debris in Florida as a result of the hot and wet summer conditions (14). This hypothesis, however, has not been tested experimentally. Because crown debris is the tissue most likely to survive intact between crop seasons, we evaluated the ability of $C$. gloeosporioides to oversummer in crown tissue under field conditions in Florida.

\section{MATERIALS AND METHODS}

The oversummer survival of C. gloeosporioides was evaluated under field conditions during 1998 and 1999 at the University of Florida Gulf Coast Research and Education Center (GCREC) at Dover. Canadian-grown green-top transplants of cultivar Camarosa were used both years. Plants were set into raised plastic-mulched beds in October of each year and grown and harvested through April. Plants used in 1998 were set in a nonfumigated soil. For the 1999 experiment, plants were set in a field that had been treated with methyl bromide and chloropicrin (98:2 at 350 $\mathrm{kg} / \mathrm{ha}$ ) prior to planting. No foliar fungicides were applied in either season. Other pesticides were applied as needed to control arthropod pests. Severe Colletotrichum spp. crown rot epidemics developed in the plots by the end of each fruiting season. In June of both years, 8 months after planting the field, plants without visible symptoms of Colletotrichum spp. crown rot were selected from an area with severe crown rot (20 to $35 \%$ of plants with crown rot symptoms). These plants were selected because already-wilted plants would have begun to decay before the start of the experiment. At 1 or 2 weeks before collecting plants for the burial studies, 10 to 20 
asymptomatic plants were assayed by plating dissected crown tissues onto a Colletotrichum spp. isolation medium (CIM) modified from Steiner and Watson (24). The medium contained $16 \mathrm{~g}$ of potato dextrose broth (Difco, Detroit), $14 \mathrm{~g}$ of agar (Difco), $250 \mathrm{mg}$ of ampicillin, $150 \mathrm{mg}$ of streptomycin sulfate, $5 \mathrm{mg}$ of iprodione (8), $100 \mu \mathrm{l}$ of Tergitol (Sigma, St. Louis), and deionized water to 1 liter. Colletotrichum spp. were detected in most of the crowns of asymptomatic plants.

The plot used for the 1998 burial study had been cropped with blueberry during the previous 4 years, but the stand had been removed and the area converted to fallow without a cover crop 12 months prior to this study. The area was rotovated $24 \mathrm{~h}$ prior to crown burial. On 4 June, 80 plants were dug from two adjacent beds (harvest field) and trimmed to clean the primary crown of leaves, roots, and secondary crowns. Two primary crowns were placed inside a porous cloth (Miracloth; Calbiochem, La Jolla, CA) bag with $50 \mathrm{cc}$ of nonfumigated soil and buried at a depth of $13 \mathrm{~cm}$ in a different location (burial field). Burial locations for the bags were organized in a randomized, complete block design with four replicates, with sampling time as treatment. At each sampling time $(0,7,14,21,42,56,70,98,119$, and 147 days after burial), one bag was recovered from each of the four replicated plots (eight crowns total). To assess the ability of C. gloeosporioides to survive in the buried crowns, crown tissue was plated onto CIM. Transverse segments, approximately $1 \mathrm{~mm}$ thick, were cut from the upper and lower portions of the crown and from two segments within the middle portion of the crown with a surface-sterilized scalpel. The segments were surface disinfected for $3 \mathrm{~min}$ in a solution of $0.2 \%$ sodium hypochlorite, then rinsed by soaking for $3 \mathrm{~min}$ in sterile deionized water. The segments were air dried on sterile paper towels, cut in half, and placed on CIM medium. All cultures were incubated for 3 to 5 days at $24^{\circ} \mathrm{C}$, with continuous fluorescent light (750 lumens and 4,100 K; Royal Phillips Electronics, Amsterdam).

For the 1999 study, the burial field had been cropped in strawberry the previous season with conventional practices, including fumigation with methyl bromide. The area was rotovated $24 \mathrm{~h}$ prior to burial of the crowns. On 11 July, 260 strawberry plants were collected from a field that had been treated with methyl bromide and chloropicrin (98:2 at $350 \mathrm{~kg} / \mathrm{ha}$ ) prior to planting (harvest field) and trimmed as described for the 1998 experiment. Individual crowns were placed inside Miracloth bags with $50 \mathrm{cc}$ of soil from the burial site. One bag was buried at each of two depths, 5 and $13 \mathrm{~cm}$, in the same location, comprising a single sample pair for each time period. Treatments were replicated 10 times and arranged in a randomized com- plete block design. Pairs of crowns were recovered from 10 burial locations at each sampling time $(0,7,14,21,28,35,42,49$, $56,70,98,119$, and 140 days after burial). After recovery, crowns were processed as in the 1998 study. In addition, crown tissue remaining after plating sections on CIM medium was cut aseptically into 3 to $6 \mathrm{~mm}$ pieces and finely ground with an electric coffee grinder (Braun, Woburn, MA) for $10 \mathrm{~s}$. The instruments were surface sterilized with $95 \%$ ethanol and air dried between samples. The ground tissue was mixed with $50 \mathrm{ml}$ of sterile deionized water and diluted tenfold during the first 6 weeks of the experiment and fivefold afterward. Then, $100 \mu \mathrm{l}$ of the suspension was plated onto CIM medium. Isolation plates were incubated at $24^{\circ} \mathrm{C}$ for 3 to 5 days under continuous fluorescent light (750 lumens and 4,100 K).

Isolation cultures were evaluated for the presence of Colletotrichum spp. with a dissecting microscope and identified on the basis of colony growth rate, coloration, and shape. After 3 to 5 days of incubation, colonies of Colletotrichum spp. were fast growing, white or orange, with or without dark centers, and had smooth borders at the edge of the colonies. Clean cultures were grown on potato dextrose agar (PDA) and then speciated microscopically based on spore morphology. C. gloeosporioides isolates had cylindrical-shaped spores, and C. acutatum isolates had fusiform-shaped spores (21). Monoconidial cultures of representative isolates were characterized further by polymerase chain reaction (PCR) amplification of the ribosomal DNA internal transcribed spacer region $(22,23)$ to confirm speciation. Conidial suspensions produced from cultures grown on PDA were used to inoculate 250-ml flasks containing $100 \mathrm{ml}$ of sterile Emerson medium (4 g of Bacto yeast extract, $15 \mathrm{~g}$ of Bacto soluble starch, $1 \mathrm{~g}$ of dibasic potassium phosphate, $0.5 \mathrm{~g}$ of magnesium sulfate, and 1 liter of distilled water). Mycelia were grown for 4 or 5 days on a shaker at $150 \mathrm{rpm}$ and then rinsed with sterile distilled water and freeze dried with a centrifugal evaporator (Jouan, Winchester, VA). DNA extraction was performed with $0.05 \mathrm{~g}$ of dried mycelium and a Fast DNA spin kit (Bio 101, Vista, CA). PCR amplifications were carried out in $20-\mu l$ mixtures containing $2 \mu \mathrm{l}$ of DNA, $2 \mu \mathrm{l}$ of $10 \times$ reaction buffer $(500 \mathrm{mM}$ Tris at $\mathrm{pH} 8.3,2.5 \mathrm{mg}$ of bovine serum albumin $/ \mathrm{ml}, 20 \mathrm{mM}$ $\mathrm{MgCl}_{2}, 5 \%$ Ficoll 400, $10 \mathrm{mM}$ Tartrazine [Idaho Technology, Salt Lake City, UT], and 1779 Ficoll/Dye), $1.2 \mu \mathrm{l}$ of $1.5 \mathrm{mM}$ $\mathrm{MgCl}_{2}, 2.0 \mu \mathrm{l}$ of $2.0 \mathrm{mM}$ deoxynucleoside triphosphate (Pharmacia P-L Biochemicals, Milwaukee, WI), $0.2 \mu \mathrm{l}$ of Taq polymerase (5 U/ $\mu \mathrm{l})$, and $10.6 \mu \mathrm{l}$ of sterile distilled water. One microliter each of the universal internal primer from the ITS4 region $\left(5^{\prime}\right.$ TCCTCCGCTTATTG-ATATGC-3') and the species-specific primer CaInt2 (5'-
GGGGAAGCCTCTCG-CGG-3'; $10 \mu \mathrm{M}$ ) for $C$. acutatum or the specific primer $\mathrm{Cg} / \mathrm{f}$ Int 1 (5'-GACCCTCCCGGCCTCCCCC3'; $10 \mu \mathrm{M})$ for $C$. gloeosporioides were used for identification $(22,23)$.

The pathogenicity of Colletotrichum spp. from buried crowns was evaluated in greenhouse experiments. Twenty isolates (5\% of the isolates recovered) were selected randomly among 403 isolates collected during the 1999 study. Seventeen of the isolates were $C$. gloeosporioides and three were $C$. acutatum. Monoconidial isolates were grown on PDA for 5 days at $24^{\circ} \mathrm{C}$, with continuous fluorescent light. For each treatment, conidia were harvested and diluted in sterile distilled water to $1 \times$ $10^{6}$ conidia $/ \mathrm{ml}$. Three strawberry plants of "Camarosa" with crowns approximately $0.5 \mathrm{~cm}$ in diameter were inoculated with a conidial suspension of a given Colletotrichum species with the use of a 1-cc insulin syringe to wound and inject $0.1 \mathrm{ml}$ of the suspension into leaf axils in the crown area. After inoculation, plants were incubated at 24 to $30^{\circ} \mathrm{C}$ for $48 \mathrm{~h}$ in a humidity chamber and then maintained in a greenhouse at the same temperature for 4 weeks. One strawberry isolate of $C$. acutatum from anthracnose fruit rot and one $C$. gloeosporioides isolate from a diseased crown (Colletotrichum crown rot) were also included in the test, and sterile distilled water was used as a control. Plants were evaluated weekly for symptoms of disease, which included wilting and plant collapse. The experiment was repeated twice. An isolate was considered to be pathogenic if two of the three inoculated plants wilted and collapsed within 30 days of inoculation. Crown segments from diseased plants were surface sterilized, sectioned, and plated onto CIM for reisolation and confirmation of the pathogen. Weather parameters during field and greenhouse experiments were recorded with dataloggers.

\section{RESULTS}

At the time of burial in 1998 (July 4), $C$. gloeosporioides was isolated from surfacesterilized crown segments taken from $87 \%$ of the crowns (Fig. 1A). Over the next 3 weeks of burial, the pathogen was isolated from $100 \%$ of the crowns. Recovery of $C$. gloeosporioides began decreasing 42 days after burial when $C$. gloeosporioides was recovered from $75 \%$ of the crowns. After 56 days of burial, the pathogen was not recovered from any of the samples. All isolates of C. gloeosporioides and C. acutatum were speciated by spore morphology, and these identifications were confirmed for representative isolates by PCR amplification of a 450- or 490-bp DNA fragment from the ribosomal DNA internal transcribed spacer region.

In 1999, after segments were surface sterilized and plated, C. gloeosporioides was recovered from $70 \%$ of the crowns at 
the time of burial (July 11) at 5 and $13 \mathrm{~cm}$ (Fig. 1A). Recovery of C. gloeosporioides increased to $100 \%$ at 14 days after burial at $13 \mathrm{~cm}$ and 21 days after burial at $5 \mathrm{~cm}$. Forty-two days after burial, the pathogen was recovered from $60 \%$ of the crowns at each depth. Seventy days after burial, only $10 \%$ of the crowns from both depths yielded C. gloeosporioides, which was not recovered on crowns at either depth after 98 days or more.

Recovery of C. gloeosporioides from ground crown tissue on dilution plates
(Fig. 1B) was similar to recovery from crown segments. C. gloeosporioides was recovered from 70 and $80 \%$ of the crowns placed at 5 or $13 \mathrm{~cm}$ deep, respectively, at the time of burial. The recovery of $C$. gloeosporioides increased to $100 \%$ at both depths after 21 days, declined to 20 to $40 \%$ after 49 days, and further declined to 10 to $20 \%$ after 70 days. The fungus was not recovered from crowns buried for 98 days or more.

When the data sets from both plating methods were combined, the recovery of

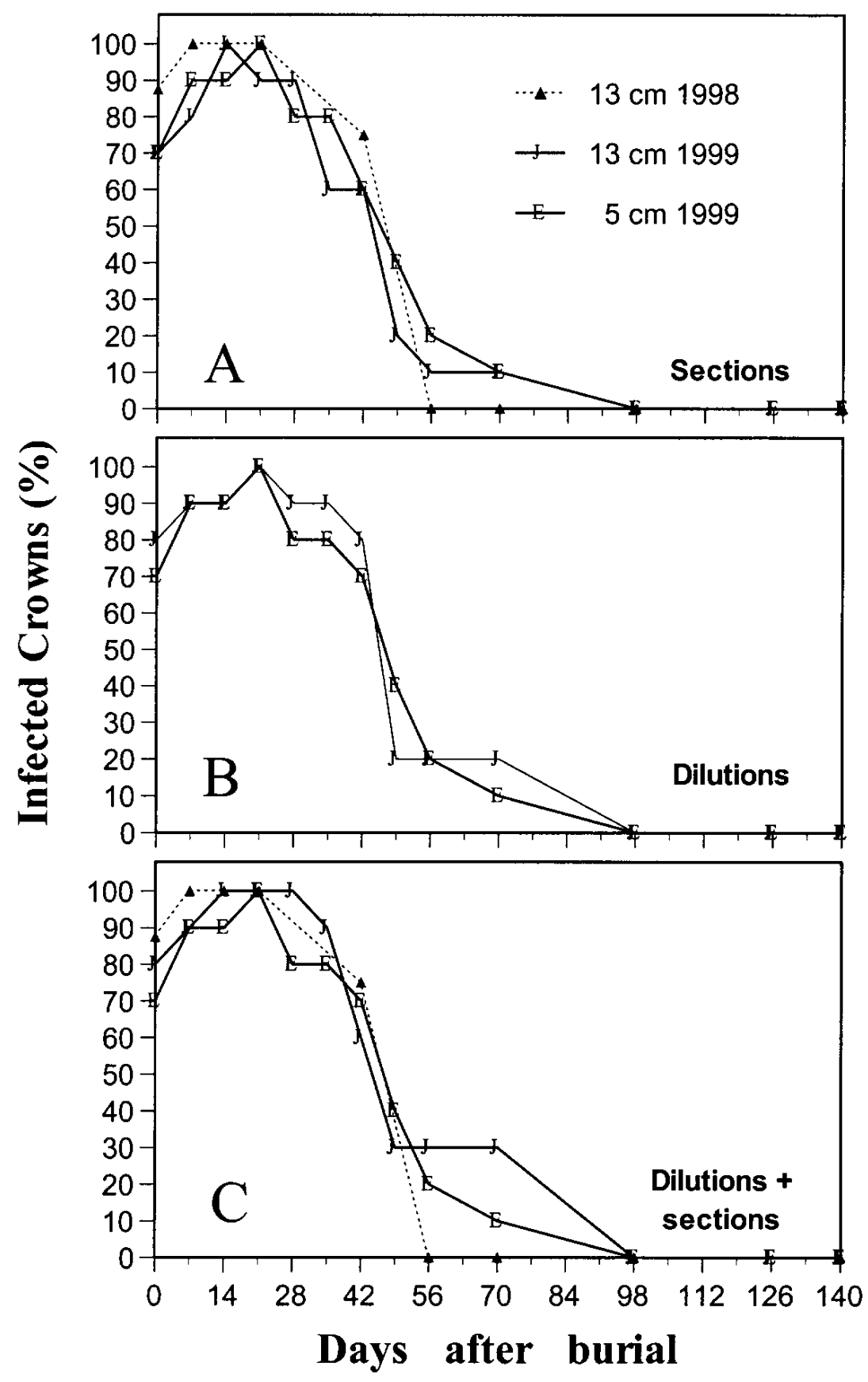

Fig. 1. Frequency of recovery of Colletotrichum gloeosporioides from buried strawberry crowns. A, Recovery from surface-sterilized crown segments buried at $13 \mathrm{~cm}$ in 1998 and 5 and $13 \mathrm{~cm}$ in 1999. B, Recovery by dilution plating of ground crown tissue buried at 5 and $13 \mathrm{~cm}$ in 1999 . C, Percentage of crowns from which C. gloeosporioides was detected from either surface-sterilized segments or dilution plating of ground tissue.

C. gloeosporioides from buried crowns was improved in comparison to either method alone (Fig. 1C). This increased recovery of $C$. gloeosporioides was the result of detecting the fungus from some of the crowns with only one of the plating methods. Specifically, in samples taken 49 , 56, and 70 days after burial, C. gloeosporioides recovery at $13 \mathrm{~cm}$ improved from $10 \%$ or 20 to $30 \%$ recovery of the pathogen when data from both methods were combined.

C. acutatum also was recovered from buried crowns but only in 1999. C. gloeosporioides was the predominant Colletotrichum species recovered throughout each year of the experiment. The recovery of $C$. acutatum was similar at both burial depths (A. R. Ureña, unpublished data) and was recovered from $60 \%$ of buried crowns after 7 and 14 days of burial. The recovery of $C$. acutatum from buried crowns declined to $30 \%$ after 28 days and was not recovered from buried crowns after 56 days of burial.

Weekly average precipitation was similar during the experiment in 1998 and 1999 (Fig. 2A). The average weekly precipitation during the burial period was $5.9 \mathrm{~mm}$ in 1998 and $5.2 \mathrm{~mm}$ in 1999 (5.4 $\mathrm{mm}$ is the 30 -year average). During the first 50 days of the burial period, precipitation was greater in 1999 than in 1998 ( 7.8 versus 4.5 $\mathrm{mm}$ weekly average precipitation). From August through September (approximately 63 to 119 days after burial), however, average weekly precipitation was higher in $1998(10.6 \mathrm{~mm})$ than in $1999(3.9 \mathrm{~mm})$.

Mean weekly air temperatures from June to October were higher in 1998 than in 1999 (27.2 versus $26.4^{\circ} \mathrm{C}$ ) and higher than the 30 -year average $\left(25.5^{\circ} \mathrm{C}\right)$. Higher temperatures were especially prevalent during the first 35 days of burial in 1998 compared with 1999 (Fig. 2B). Average weekly soil temperatures were 2 or $3^{\circ} \mathrm{C}$ higher than air temperatures during 1998 and 1999 (Fig. 2B and C). Average weekly soil temperatures were higher during the first 50 days of the burial period in 1998 than in 1999 (Fig. 2C). Soil temperatures were not recorded between 25 July and 16 August, 1998, because of equipment malfunction. Daily soil moisture content (water potential) was recorded in 1999 (Fig. 2D). The lowest water potential $(-0.022 \mathrm{Mpa})$ occurred 42 days after burial and corresponded with the maximum average soil temperature $\left(32.2^{\circ} \mathrm{C}\right)$, the highest air temperature $\left(29^{\circ} \mathrm{C}\right)$, and reduced precipitation (2 mm) in 1999 (Fig. 2).

Fourteen of seventeen C. gloeosporioides isolates obtained from buried crowns and tested under greenhouse conditions were pathogenic and produced typical crown rot symptoms on strawberry (i.e., plant wilting and death). Three isolates of C. gloeosporioides and all three crown isolates of $C$. acutatum evaluated were nonpathogenic. Crowns of plants inoculated with pathogenic isolates exhibited 
abundant necrosis and reddish brown streaks. Plants inoculated with isolates of C. gloeosporioides obtained from diseased crowns developed typical crown rot symptoms, whereas inoculation with $C$. $a c u$ tatum isolated from diseased fruit did not. No symptoms of Colletotrichum crown rot developed in the sterile water-inoculated controls.

\section{DISCUSSION}

C. gloeosporioides did not oversummer in buried strawberry crowns long enough to be a major source of primary inoculum for Colletotrichum crown rot epidemics in fruit production fields in Florida. Although C. gloeosporioides was isolated frequently from strawberry crowns early in the burial period, it declined quickly to undetectable levels within 56 to 98 days of burial. Because the time period between the incorporation of strawberry debris into the soil at the end of one season and transplanting for the subsequent season usually is 120 to 180 days, there is sufficient time for strawberry crowns to decay and $C$. gloeosporioides inoculum to be eliminated.

Following an initial increase in the detection of $C$. gloeosporioides during the first 3 to 4 weeks of burial, recovery of the pathogen decreased. C. gloeosporioides was not recovered from buried crowns 56 days after burial in 1998 or 98 days after burial in 1999. These results suggest that C. gloeosporioides does not survive in buried strawberry crowns in Florida long enough to be an important source of primary inoculum for crown rot epidemics, even though strawberries are replanted in the same field every year. Several production practices in Florida limit the opportunities for the inoculum of Colletotrichum spp. to oversummer in plant debris or soil. Within 1 month after the end of the season (late March or early April), plants typically are killed. Growers may remove the plastic mulch and incorporate plant material into the soil at this time or use the herbicide paraquat to kill the plants and then use the existing beds for a spring vegetable crop. Under these circumstances, strawberry debris would not be incorporated until May, after the vegetable crop is harvested. These experiments simulated a worst-case situation, where strawberry plants would be grown until incorporated at the end of a late vegetable crop in early June. In most commercial situations, the strawberry plants would have been killed 1 to 2 months earlier. After a summer cover crop of grain or legumes is grown and eventually incorporated in August, the fields are fumigated with a mixture of methyl bromide-chloropicrin and beds for the next season are formed in September and October. Fumigation with methyl bromide also eliminates Colletotrichum spp. from soil (7).

Previous studies have shown longer survival times for Colletotrichum spp. in strawberry debris. In Louisiana, inoculum of $C$. fragariae was able to survive up to 7 months in crowns of whole strawberry plants kept at $5^{\circ} \mathrm{C}(12)$. C. acutatum survived from November to July in buried runner segments placed 5 to $7 \mathrm{~cm}$ deep in northern California (7). Environmental conditions during the summer in westcentral Florida, however, are dramatically different from winter in Louisiana or northern California. It is likely that the lower temperatures during the studies in Louisiana and California would extend the survival of Colletotrichum spp. in plant debris. It has been hypothesized that survival of $C$. acutatum may improve at lower temperatures (7). This may be the result of reduced colonization of plant debris by the pathogen and increased colonization by other soilborne microorganisms that would compete for nutrients in the crown tissue at high temperatures $(5,7)$. Hot and wet summers in Florida would facilitate the rapid colonization and breakdown of strawberry plant debris. In our experiments, the pith of buried crowns decom-
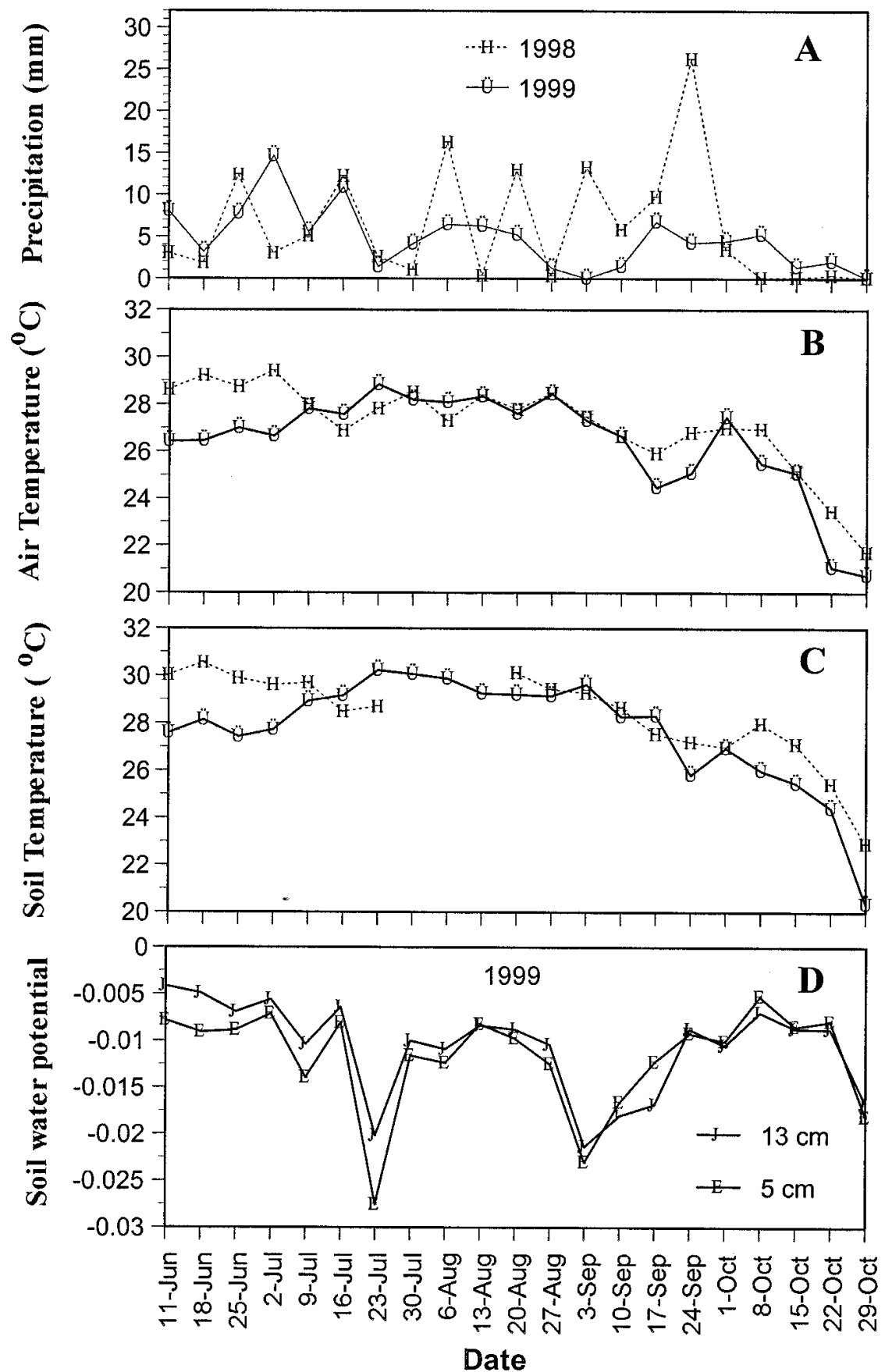

Fig. 2. A, Weekly precipitation, B, weekly average air temperature, $\mathbf{C}$, weekly soil temperature, and D, average weekly soil water potential during summer and fall of 1998 and 1999. No soil temperature data was recorded 23 July to 6 August, 1998. Average weekly soil water potential (D) recorded at 5 and $13 \mathrm{~cm}$ during the summer and fall of 1999. All observations were made at the University of Florida, Gulf Coast Research and Education Center, Dover. 
posed completely by late October and November, leaving a hollow crown with only the woody cortex remaining. Because the pathogen was no longer recovered from crowns at the end of the experiment, this observation supports the suggestion that most of the pith tissue had been colonized and decomposed by the end of the experiments, leaving little substrate for survival of the pathogen.

Soil moisture content may have affected the survival of $C$. gloeosporioides in buried strawberry crowns by affecting fungus activity or by indirectly disrupting the activity of its competitors. The effects of soil moisture content on survival of Colletotrichum spp. are documented $(5,17)$. When inoculated, strawberry petioles were buried in an air-dried or flooded soil for 7 weeks at $25^{\circ} \mathrm{C}$, and $C$. acutatum was detected from 60 and $0 \%$ of the petioles, respectively (5). In Florida, the survival of C. acutatum in infected plant debris of leatherleaf fern or in soil increased with the reduction in soil moisture (17). Although the effect of variations in moisture and temperature on the survival of $C$. gloeosporioides in strawberry crowns is unclear, it is likely that it would behave similarly to $C$. acutatum in plant debris or soil.

The lower precipitation recorded from August to September 1999 compared with the same period in 1998 reduced the moisture content of the soil. This situation may have affected the ability of Colletotrichum spp. to survive by influencing the activity of other organisms. The competitive saprophytic ability of Trichoderma harzianum in buried plant tissues is reduced when the soil is flooded or when there is a drastic reduction in the moisture content of the soil (6). Tissue plated onto CIM in July 1998 produced large numbers of colonies of Fusarium and Trichoderma spp., with the latter abundantly growing out of segments that were plated at the end of July (A. R. Ureña, unpublished data). In 1999, the increased recovery of these species from crown segments was not observed until late August. In addition to environmental differences between the 1998 and 1999 experiments, the crowns in 1999 were grown and buried in soil that had been fumigated with methyl bromide, whereas in 1998, the sites were not fumigated. Soil fumigation affects the activity of microbes in treated soil $(26,28)$. Thus, the extended survival of $C$. gloeosporioides in 1999 may have been caused by differences in microbial activity resulting from environmental conditions or soil fumigation.

Most isolates of C. gloeosporioides caused Colletotrichum crown rot symptoms in the greenhouse bioassay, but none of the $C$. acutatum isolates caused crown rot. These results support the observation that Colletotrichum crown rot epidemics in
Florida are caused by $C$. gloeosporioides $(15,25)$. It is unclear why some of the $C$. gloeosporioides isolates recovered from buried crowns did not cause crown rot in the bioassay. A possible explanation is that not all of the C. gloeosporioides isolates recovered from strawberry tissue are pathogenic on strawberry. The plants used for the burial studies did not have symptoms of Colletotrichum crown rot at the time of collection, and the detached crowns could have been colonized by nonpathogenic isolates of $C$. gloeosporioides. Crown rot bioassays of isolates of $C$. gloeosporioides recovered from strawberry petioles also identified isolates that did not cause crown rot (D. E. Legard, unpublished data).

These results show that propagules of $C$. gloeosporioides in buried strawberry crowns are not likely to be an important source of inoculum for Colletotrichum crown rot epidemics in Florida. Other sources of inoculum such as infected or infested transplants or alternate hosts may be more important in the epidemiology of Colletotrichum crown rot in Florida. As a result of the potential for some survival of inoculum in well-preserved strawberry debris, however, it is prudent that growers use cultural practices that promote the breakdown of crown tissue in the soil. More research is necessary to further elucidate sources of primary inoculum for Colletotrichum crown rot epidemics in Florida.

\section{ACKNOWLEDGMENTS}

We thank U. Benny, C. L. Xiao, L. Smith, and the field crew and OPS personnel of the GCRECDover for their valuable assistance.

\section{LITERATURE CITED}

1. Aerts, M. J., and Nesheim, O. N. 1997. Strawberry integrated pest management and pesticide use survey for 1995. Pesticide Information Office, IFAS, University of Florida, Gainesville.

2. Bosshard, E. 1997. Why is Colletotrichum acutatum a quarantine organism, and $C$. gloeosporioides and C. fragariae are not? Acta Hortic. 439:799-802.

3. Brooks, A. N. 1932. A study of strawberry wilt or crown rot. Pages 144-145 in: Florida Agricultural Experimental Station Annual Report, Gainesville.

4. Denoyes, B., and Baudry, A. 1995. Species identification and pathogenicity study of French Colletotrichum strains isolated from strawberry using morphological and cultural characteristics. Phytopathology 85:53-57.

5. Eastburn, D. M. 1992. Effects of soil moisture and temperature on the survival of Colletotrichum acutatum. Plant Dis. 76:841-842.

6. Eastburn, D. M., and Butler, E. E. 1991. Effects of soil moisture and temperature on the saprophytic ability of Trichoderma harzianum. Mycologia 83:257-263.

7. Eastburn, D. M., and Gubler, W. D. 1990. Strawberry anthracnose: Detection and survival of Colletotrichum acutatum in soil. Plant Dis. 74:161-163.

8. Freeman, S., and Katan, T. 1997. Identification of Colletotrichum species responsible for anthracnose and root necrosis of strawberry in
Israel. Phytopathology 87:516-521.

9. Freeman, S., Nizami, Y., Dotan, S., Even, S., and Sando, T. 1997. Control of Colletotrichum acutatum in strawberry under laboratory, greenhouse, and field conditions. Plant Dis. 81:749-752.

10. Henz, G. P., Boiteux, L. S., and Lopes, C. A. 1992. Outbreak of strawberry anthracnose caused by Colletotrichum acutatum in central Brazil. Plant Dis. 76:212.

11. Horn, N. L., and Carver, R. G. 1963. A new crown rot of strawberry plants caused by $\mathrm{Col}$ letotrichum fragariae. Phytopathology 53:768-770.

12. Horn, N. L., and Carver, R. B. 1968. Overwintering of Colletotrichum fragariae in strawberry crowns. Phytopathology 58:540541.

13. Howard, C. M., and Albregts, E. E. 1984. Anthracnose of strawberry fruit caused by Glomerella cingulata in Florida. Plant Dis. 68:824-825.

14. Howard, C. M., Maas, J. L., Chandler, C. K., and Albregts, E. E. 1992. Anthracnose of strawberry caused by the Colletotrichum complex in Florida. Plant Dis. 76:976-981.

15. Legard, D. E., Whidden, A. J., and Chandler, C. K. 1998. Incidence and occurrence of strawberry diseases in Florida from 19911996. Adv. Strawberry Res. 16:35-47.

16. McInnes, T. B., Black, L. L., and Gatti, J. M., Jr. 1992. Disease-free plants for management of strawberry anthracnose crown rot. Plant Dis. 76:260-264.

17. Norman, D. J., and Strandberg, J. O. 1997. Survival of Colletotrichum acutatum in soil and plant debris of leatherleaf fern. Plant Dis. 81:1177-1180.

18. Smith, B. J., and Black, L. L. 1987. Resistance of strawberry plants to Colletotrichum fragariae affected by environmental conditions. Plant Dis. 71:834-837.

19. Smith, B. J., and Black, L. L. 1986. First report of Colletotrichum acutatum on strawberry in the United States. Plant Dis. 70:1074

20. Smith, B. J. 1998. Anthracnose crown rot Pages 46-48 in: Compendium of Strawberry Diseases, 2nd ed. J. L. Mass, ed. American Phytopathological Society, St. Paul, MN.

21. Smith, B. J., and Black, L. L. 1990. Morphological, cultural, and pathogenic variation among Colletotrichum species isolated from strawberry. Plant Dis. 74:69-76.

22. Sreenivasaprasad, S., Mills, P. R., Meehan, B. M., and Brown, A. E. 1996. Phylogeny and systematics of 18 Colletotrichum species based on ribosomal DNA spacer sequences. Genome 39:499-512.

23. Sreenivasaprasad, S., Sharada, K., Brown, A. E., and Mills, P. R. 1996. PCR-based detection of Colletotrichum acutatum on strawberry. Plant Pathol. 45:650-655.

24. Steiner, G. W., and Watson, R. D. 1965. Use of surfactants in the soil dilution and plate count method. Phytopathology 55:728-730.

25. Ureña-Padilla, A., Kistler, H. C., and Legard, D. E. 2000. Etiology and population genetics of Collecotrichum spp. responsible for diseases of strawberry. (Abstr.) Phytopathology 90:S79.

26. Warcup, J. H. 1976. Studies on soil fumigation IV: Effects on fungi. Soil Biol. Biochem. 8:261-266.

27. Wilson, L. L., Madden, L. V., and Ellis, M. A. 1992. Overwinter survival of Colletotrichum acutatum in infected strawberry fruit in Ohio. Plant Dis. 76:948-950.

28. Yeates, G. W., Bamforth, S. S., Ross, D. J., Tate, K. R., and Sparling, G. P. 1991. Recolonization of methyl bromide sterilized soils under four different field conditions. Biol. Fertil. Soils 11:181-189. 